\title{
$\checkmark$ Research Square \\ Effects of Terminalia chebula Retz. on the Secretion of Somatostatin in the Small Intestine in Mice
}

\section{Min He ( $\nabla$ hemin09@163.com )}

Sichuan Agricultural University

\section{Si-Qi Zhao}

Sichuan Agricultural University

\section{Xi-Yan Guo}

Sichuan Agricultural University

\section{Short Report}

Keywords: Terminalia chebula Retz., Somatostatin (SS), Immunohistochemistry, Intestines

Posted Date: April 19th, 2021

DOI: https://doi.org/10.21203/rs.3.rs-440387/v1

License: (1) This work is licensed under a Creative Commons Attribution 4.0 International License. Read Full License 


\section{Abstract}

Objective: This study investigated the effects of Terminalia chebula Retz. (TC) and its two processed products Rubia cordifolia L. per Terminalia chebula Retz. (RTC) and Euphorbia fischeriana Steud per Terminalia chebula Retz. (ETC) on the secretory activity of somatostatin cells in the small intestine in mice.

Methods: A total of 168 twenty-day-old SPF Kunming mice were randomly divided into seven groups, i.e., the control (saline, $0.1 \mathrm{~g} / \mathrm{kg}$ ), high TC, RTC, ETC and low TC, RTC, and ETC groups, and administered drugs for 28 days. The cellular localization and expression of SS in the small intestine were assessed by immunohistochemistry after drug delivery for $7,14,21$ or 28 days.

Results: The somatostatin $₫ S S \bigotimes$ protein was widely distributed in the small intestines of mice. Immunoreactivity gradually decreased in the duodenum to the ileum. SS immunoreactivity was significantly lower in the high TC, RTC, ETC and low RTC, and ETC groups compared with the control group after drug delivery for 28 days. The efficacy of RTC was better than that of ETC and obviously better than that of TC. The efficacies of high dosages of TC and its processed products were better than those of low dosages of the drugs. SS cells of various shapes, including cone-, spindle-, and ellipseshaped SS cells, were observed. A large number of SS cells were found in the intestinal gland epithelium and intestinal lamina propria in the control group, and these cells were widely distributed in epithelial cells in the intestinal mucosa and intestinal gland epithelium in the experimental groups.

Conclusions: This study indicates that TC and its processed products play an important role in inhibiting the secretion of SS to different degrees. The effect of the RTC at a dosage of $4.0 \mathrm{~g} \cdot \mathrm{kg}^{-1} \mathrm{BW}$ is the best.

\section{Introduction}

Terminalia chebula Retz. (TC) is known as the "king of Tibetan medicine" in Tibetan medicine and Mongolian medicine due its various effects, i.e., its inhibitory effects on free radicals and its antitumor, bacteriostatic, spasmolytic and detoxification effects ${ }^{[1-2]}$. In recent years, many scholars have found that Terminalia chebula Retz. (TC) extract has good preventive and therapeutic effects on gastrointestinal diseases, implying that TC has a certain regulatory effect on digestive function. However, the effect of TC on the digestive tract has not been sufficiently studied ${ }^{[1,3]}$. The utilization rate of TC when applied directly is low, and Tibetan medicine processing is usually adopted to enhance its efficacy ${ }^{[4]}$. In this study, Rubia cordifolia L. per Terminalia chebula Retz. (RTC) and Euphorbia fischeriana Steud per Terminalia chebula Retz. (ETC) were obtained by the ashed method and the boiled method. RTC is a mild drug that is mostly used for the treatment of mild illness, and its medicinal properties are mild. ETC is a strong drug that is mostly used to treat serious diseases, and its drug properties are very strong ${ }^{[5]}$.

Somatostatin (SS) cells are important endocrine cells in the digestive tract that inhibit the secretion of many gastrointestinal hormones ${ }^{[6]}$. Extensive functional and morphological research has demonstrated 
the pivotal role of SS in the regulation of a wide variety of gastrointestinal activities ${ }^{[7]}$. In this experiment, we selected TC as the research object and used immunohistochemistry to study the effects of RTC and ETC to determine the influences of different processed products of TC on SS morphology, distribution and secretion, broaden the clinical application and optimize the processing of these products, and promote their development and application in the clinic.

\section{Materials And Methods Plant Materials}

Terminalia chebula, Rubia cordifolia L. and Euphorbia fischeriana Steud were obtained from a local supermarket in Sichuan (China) and authenticated by associate professor Fan QJ of the Department of Pharmacy at Sichuan Agricultural University, Sichuan, China.

\section{Preparation of Processed Products}

For drug processing, improvements were made to the methods reported by Mao and colleagues ${ }^{[8]}$.

Preparation of RTC: Rubia cordifolia L. was burnt to ash. TC and Rubia cordifolia L. were mixed in a 1:3 ratio with wheat wine. The mixture was heated in a pot to $75^{\circ} \mathrm{C}$. Then, an appropriate amount of TC was added, and the fire was quickly extinguished. The TC was soaked in the pot at $25^{\circ} \mathrm{C}$ for 1 day. On the second day, the TC was removed and kneaded. Then, the TC was washed with distilled water 3 times and dried at $70^{\circ} \mathrm{C}$ for $30 \mathrm{~h}$.

Preparation of ETC: TC and Euphorbia fischeriana Steud were mixed at a ratio of 1:1, water was added at a ratio of 1:15, the mixture was boiled for $30 \mathrm{~min}$, and the liquid was extracted and preserved. The TC was added to the solution and soaked at $25^{\circ} \mathrm{C}$ for 2 days. Then, the TC was placed in the abovementioned solution, simmered until the liquid evaporated and dried at $60^{\circ} \mathrm{C}$ for $35 \mathrm{~h}$.

\section{Experimental animals}

A total of 168 21-day-old SPF Kunming mice (obtained from Chengdu Dashuo Technology Co., Ltd., certificate no: SCXK 2008-24) were randomly divided into seven groups: the control, high TC, RTC, ETC (4 $\mathrm{g} / \mathrm{kg}$ ) and low TC, RTC, and ETC ( $1 \mathrm{~g} / \mathrm{kg})$ groups ( $\mathrm{n}=24$ in each group). The mice were housed in a SPF animal room at $23-25^{\circ} \mathrm{C}$ and provided a standard diet and tap water ad libitum throughout the 28-day experimental period. The experimental groups were given prepared solutions containing different concentrations of the drugs, while the control groups were administered an equal volume of saline by gastric perfusion once per day. All animal procedures were approved by the Sichuan Agricultural University Animal Care and Use Committee. Each group was given the prescribed dose by gavage, while the blank control group was given an equal volume of saline.

\section{Main reagents}


An SABC immunohistochemistry kit (product code: SA1020), a rabbit anti-SS polyclonal antibody (product code: BA0124), and DAB chromogenic reagent (product code: AR1022) were purchased from Wuhan Boster Biological Technology Co., Ltd. (China).

\section{Immunohistochemical Staining}

On the 7th, 14th, 21st and 28th days of the experiment, the rats were dissected according to the animal dissection guidelines of Sichuan Agricultural University $1 \mathrm{~h}$ after the last administration. Segments of the duodenum, jejunum and ileum $(1 \mathrm{~cm})$ of 6 mice from each group were taken, fixed with $4 \%$ paraformaldehyde for $24 \mathrm{~h}$, and embedded in paraffin. Then, the tissues were sliced into serial sections with a thickness of $5 \mu \mathrm{m}$ with a Leica RM 2135 paraffin slicer.

Immunohistochemical staining was performed according to the instructions of the SABC immunohistochemistry kit. After dewaxing, the slices were washed with $0.01 \mathrm{~mol} / \mathrm{L}$ phosphate buffered saline (PBS, pH 7.4) 3 times. Then, the slices were heated in a microwave, subjected to antigen retrieval and incubated with $3 \% \mathrm{H}_{2} \mathrm{O}_{2}$ for 30 min. The primary antibody was a rabbit anti-SS polyclonal antibody (1:100), and PBS was used instead of primary antibody in the negative control group. The slices were incubated with primary antibody for $17 \mathrm{~h}$ at $4^{\circ} \mathrm{C}$ and for $30 \mathrm{~min}$ at $25^{\circ} \mathrm{C}$. Then, they were washed with PBS 3 times. The slices were incubated with secondary antibody (biotinylated goat anti-rabbit $\lg G, 1: 100$ ) for 30 min, washed with PBS 3 times, and developed with diaminobenzidine. The slices were counterstained with hematoxylin, dehydrated, and mounted.

\section{Observations and Statistical Analysis}

The stained slices were observed under an Olympus BH-2 microscope. A total of 10 fields (400X) from each tissue section were randomly selected for cell counting. The integrated optical density (IOD) and mean gray value of SS staining in each field (400X) were measured with a Jiangsu JETDA801 morphological image analysis system.

The cell density data are expressed as the mean \pm standard deviation. Duncan's multiple comparison method and $t$ tests were performed in this study $(P<0.05$ indicates a significant difference). SPSS 20.0 software was used for statistical analysis of biological data.

\section{Results}

\section{TC and its processed products reduced the number of SS cells in the intestinal glands and lamina propria}

The results showed that SS cells were distributed in duodenal, jejunal, and ileal segments (Fig. 1a $\sim$ f). The number of SS cells in each intestinal segment was decreased in the drug-treated groups compared with the control group (Table 1). In the duodenum and jejunum, SS cells were mainly located between the intestinal mucosal epithelial cells and the intestinal glandular epithelium, but fewer cells were observed in the intestinal lamina propria (Fig. 1a d). In the ileum, SS cells were mostly distributed in the intestinal 
glandular epithelium and lamina propria, and only a small number of them were distributed among epithelial cells in the intestinal mucosa (Fig. 1e $\sim$ f). In the control group, SS cells were mainly distributed in the duodenal glandular epithelium, the intestinal glandular epithelium of jejunum and ileum, and the intestinal intrinsic membrane. In the drug administration groups, SS cells were mostly distributed among intestinal mucosal epithelial cells, and a few were distributed in the lamina propria. After drug administration, the secretion of SS in the small intestinal glands and the intrinsic membrane of the duodenum and jejunum was reduced in both the high and low RTC groups. Moreover, the secretion of SS in the ileal glandular epithelium in the high ETC group was decreased (Fig. 1). 
Table 1

SS cell number in the small intestine $\left(\mathrm{n} / 0.064 \mathrm{~mm}^{2}\right)$

\begin{tabular}{|c|c|c|c|c|c|c|c|c|}
\hline & \multirow[t]{2}{*}{ day } & \multirow{2}{*}{$\begin{array}{l}\text { Control } \\
\text { group }\end{array}$} & \multirow{2}{*}{$\begin{array}{l}\text { high } \\
\text { TC } \\
\text { group }\end{array}$} & \multirow{2}{*}{$\begin{array}{l}\text { LOW } \\
\text { TC } \\
\text { group }\end{array}$} & \multirow{2}{*}{$\begin{array}{l}\text { high RTC } \\
\text { group }\end{array}$} & \multirow{2}{*}{$\begin{array}{l}\text { LOW } \\
\text { RTC } \\
\text { group }\end{array}$} & \multirow{2}{*}{$\begin{array}{l}\text { high ETC } \\
\text { group }\end{array}$} & \multirow{2}{*}{$\begin{array}{l}\text { LOW } \\
\text { ETC } \\
\text { group }\end{array}$} \\
\hline & & & & & & & & \\
\hline \multirow[t]{4}{*}{ duodenum } & 7 & $\begin{array}{l}5.52 \pm \\
1.00\end{array}$ & $\begin{array}{l}4.78 \pm \\
1.02\end{array}$ & $\begin{array}{l}5.12 \pm \\
1.08\end{array}$ & $\begin{array}{l}4.01 \pm \\
1.10 \star \star\end{array}$ & $\begin{array}{l}3.88 \pm \\
2.01^{\star \star}\end{array}$ & $\begin{array}{l}4.28 \pm \\
1.99 \star \star\end{array}$ & $\begin{array}{l}4.63 \pm \\
0.94^{\star}\end{array}$ \\
\hline & 14 & $\begin{array}{l}7.46 \pm \\
1.05\end{array}$ & $\begin{array}{l}6.25 \pm \\
1.01^{\star \star}\end{array}$ & $\begin{array}{l}6.54 \pm \\
1.04^{\star}\end{array}$ & $\begin{array}{l}5.23 \pm \\
1.01^{\star \star}\end{array}$ & $\begin{array}{l}5.30 \pm \\
2.00^{\star \star}\end{array}$ & $\begin{array}{l}5.47 \pm \\
1.10^{\star \star}\end{array}$ & $\begin{array}{l}5.97 \pm \\
0.84^{\star \star}\end{array}$ \\
\hline & 21 & $\begin{array}{l}8.55 \pm \\
1.06\end{array}$ & $\begin{array}{l}7.41 \pm \\
0.50 \star \star\end{array}$ & $\begin{array}{l}7.64 \pm \\
1.02^{\star}\end{array}$ & $\begin{array}{l}5.66 \pm \\
0.80^{\star \star}\end{array}$ & $\begin{array}{l}6.02 \pm \\
1.30 \star \star\end{array}$ & $\begin{array}{l}6.19 \pm \\
0.96^{\star \star}\end{array}$ & $\begin{array}{l}7.05 \pm \\
0.80 \star \star\end{array}$ \\
\hline & 28 & $\begin{array}{l}9.91 \pm \\
1.11\end{array}$ & $\begin{array}{l}8.04 \pm \\
0.40 * \star\end{array}$ & $\begin{array}{l}8.67 \pm \\
0.20 \star \star\end{array}$ & $\begin{array}{l}6.20 \pm \\
0.20 \star \star\end{array}$ & $\begin{array}{l}6.60 \pm \\
0.10 \star \star\end{array}$ & $\begin{array}{l}7.06 \pm \\
0.84^{\star \star}\end{array}$ & $\begin{array}{l}7.69 \pm \\
1.03^{\star \star}\end{array}$ \\
\hline \multirow[t]{4}{*}{ jejunum } & 7 & $\begin{array}{l}4.78 \pm \\
1.10\end{array}$ & $\begin{array}{l}3.18 \pm \\
0.73^{\star \star}\end{array}$ & $\begin{array}{l}3.83 \pm \\
2.02\end{array}$ & $\begin{array}{l}2.39 \pm \\
1.05^{\star \star}\end{array}$ & $\begin{array}{l}2.80 \pm \\
0.52^{\star \star}\end{array}$ & $\begin{array}{l}2.81 \pm \\
2.20^{\star \star \star}\end{array}$ & $\begin{array}{l}4.90 \pm \\
1.12^{\star \star}\end{array}$ \\
\hline & 14 & $\begin{array}{l}6.19 \pm \\
1.10\end{array}$ & $\begin{array}{l}4.36 \pm \\
0.61^{\star \star}\end{array}$ & $\begin{array}{l}4.57 \pm \\
0.35^{\star \star}\end{array}$ & $\begin{array}{l}3.23 \pm \\
0.93^{\star \star}\end{array}$ & $\begin{array}{l}3.67 \pm \\
0.47 \star \star\end{array}$ & $\begin{array}{l}3.82 \pm \\
0.73^{\star \star}\end{array}$ & $\begin{array}{l}4.24 \pm \\
1.25^{\star \star}\end{array}$ \\
\hline & 21 & $\begin{array}{l}7.10 \pm \\
2.01\end{array}$ & $\begin{array}{l}5.14 \pm \\
0.40^{\star \star}\end{array}$ & $\begin{array}{l}5.94 \pm \\
0.73^{\star \star}\end{array}$ & $\begin{array}{l}3.77 \pm \\
0.78^{\star \star}\end{array}$ & $\begin{array}{l}4.49 \pm \\
1.18\end{array}$ & $\begin{array}{l}4.62 \pm \\
0.73^{\star \star}\end{array}$ & $\begin{array}{l}4.81 \pm \\
1.38^{\star \star \star}\end{array}$ \\
\hline & 28 & $\begin{array}{l}7.92 \pm \\
1.03\end{array}$ & $\begin{array}{l}5.85 \pm \\
0.32^{\star \star}\end{array}$ & $\begin{array}{l}6.62 \pm \\
0.25^{\star \star}\end{array}$ & $\begin{array}{l}4.26 \pm \\
0.30 \star \star\end{array}$ & $\begin{array}{l}4.98 \pm \\
0.52^{\star \star}\end{array}$ & $\begin{array}{l}5.18 \pm \\
0.64 \star \star\end{array}$ & $\begin{array}{l}5.63 \pm \\
0.39 * \star\end{array}$ \\
\hline \multirow[t]{4}{*}{ ileum } & 7 & $\begin{array}{l}3.13 \pm \\
1.02\end{array}$ & $\begin{array}{l}2.45 \pm \\
0.48^{\star}\end{array}$ & $\begin{array}{l}2.78 \pm \\
0.69\end{array}$ & $\begin{array}{l}1.87 \pm \\
0.94^{\star \star}\end{array}$ & $\begin{array}{l}2.03 \pm \\
0.41^{\star \star}\end{array}$ & $\begin{array}{l}2.14 \pm \\
0.38^{\star \star}\end{array}$ & $\begin{array}{l}2.27 \pm \\
0.93^{\star \star}\end{array}$ \\
\hline & 14 & $\begin{array}{l}4.12 \pm \\
0.91\end{array}$ & $\begin{array}{l}3.22 \pm \\
0.59 * \star\end{array}$ & $\begin{array}{l}3.55 \pm \\
0.48\end{array}$ & $\begin{array}{l}2.47 \pm \\
0.98^{\star \star}\end{array}$ & $\begin{array}{l}2.61 \pm \\
0.43^{\star \star}\end{array}$ & $\begin{array}{l}2.82 \pm \\
0.36^{\star \star}\end{array}$ & $\begin{array}{l}3.23 \pm \\
0.95^{\star \star}\end{array}$ \\
\hline & 21 & $\begin{array}{l}4.95 \pm \\
1.03\end{array}$ & $\begin{array}{l}3.84 \pm \\
0.61 * \star\end{array}$ & $\begin{array}{l}4.45 \pm \\
0.43\end{array}$ & $\begin{array}{l}2.91 \pm \\
1.08^{\star \star}\end{array}$ & $\begin{array}{l}3.19 \pm \\
1.43^{\star \star}\end{array}$ & 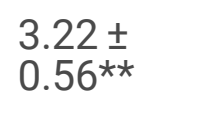 & $\begin{array}{l}3.63 \pm \\
0.86^{\star \star}\end{array}$ \\
\hline & 28 & $\begin{array}{l}5.77 \pm \\
1.09\end{array}$ & $\begin{array}{l}4.24 \pm \\
0.30^{\star \star}\end{array}$ & $\begin{array}{l}5.03 \pm \\
0.37^{\star \star}\end{array}$ & $\begin{array}{l}3.17 \pm \\
1.00 \star \star\end{array}$ & $\begin{array}{l}3.82 \pm \\
1.39 \star \star\end{array}$ & $\begin{array}{l}3.80 \pm \\
0.58^{\star \star}\end{array}$ & $\begin{array}{l}4.23 \pm \\
0.55^{\star \star}\end{array}$ \\
\hline
\end{tabular}

\section{TC and its processed products reduced the SS immune response in the small intestine}

Figure 2 shows that TC and its processed products had a decreasing effect on the IOD of SS immunoreactivity in endocrine cells in the small intestine, and the decreasing effect gradually increased 
with prolongation of drug administration. After 7 days of administration, the IOD of SS immunoreactivity in the small intestine in the low and high RTC groups was significantly decreased $(p<0.01)$. After 7 and 14 days of administration, the IOD of SS immunoreactivity in the small intestine in the high and low ETC groups was significantly decreased $(P<0.01)$. The IOD of SS immunoreactivity in the small intestine in the high and low TC groups was also significantly decreased $(P<0.01)$. After 14 days of administration, the IOD of SS immunoreactivity in the small intestine in the high RTC group was significantly lower than that in the low TC group $(P<0.01)$. After 21 days of administration, the IOD of SS immunoreactivity was significantly lower in the high RTC group than in the high TC group $(\mathrm{P}<0.01)$. Moreover, the IOD of SS immunoreactivity in the low RTC group was significantly lower than that in the low TC group $(P<0.01)$. The IOD of SS immunoreactivity in the small intestine in the high ETC group was significantly lower than that in the low TC group $(P<0.01)$. After 28 days of administration, the IOD of SS immunoreactivity in the small intestine in the high RTC group was significantly lower than that in both the high and low ETC groups $(P<0.01)$ and significantly lower than that in the high TC group $(P<0.01$ or $0.01<P<0.05)$. Furthermore, compared with that in the low TC group, the IOD of SS immunoreactivity in the small intestine in the low ETC group was significantly decreased $(P<0.01)$.

The IOD of SS immunoreactivity in the small intestine in the high TC group was significantly lower than that in the low TC group $(P<0.01$ or $0.01<P<0.05)$. After 14,21 and 28 days of administration, the effects of high doses of Terminalia chebula and its processed products on the IOD of SS immunoreactivity in the small intestine were significantly stronger than those of low doses of these drugs.

The results of grayscale analysis (Fig. 3) showed that TC and its processed products had an increasing effect on the average grayscale value of SS immunoreactivity in endocrine cells in each segment of the small intestine and that the increasing effect was gradually enhanced with prolongation of drug administration. After 7 days of administration, the gray value of SS immunoreactivity in the small intestine in the high and low RTC groups was significantly increased $(P<0.01)$. The gray values of SS immunoreactivity in the small intestine in the high and low ETC groups were significantly increased after 21 and 28 days of administration ( $p<0.01$ ). The gray value of SS immunoreactivity in each segment of the small intestine in the high TC group was significantly increased after 28 days of administration $(\mathrm{P}<$ 0.05). The gray value in the SS immunoreactivity in the small intestine in the high RTC group was significantly higher than that in the low TC group after 7 days of administration $(P<0.01)$. After 14 days of administration, the gray value of SS immunoreactivity was significantly higher in the high RTC group than in the high TC group $(P<0.01)$. After 21 days of administration, the gray value of SS immunoreactivity was significantly higher in the high RTC group than the low ETC group $(P<0.01)$. After 28 days of administration, the gray value of SS immunoreactivity was significantly higher in the high RTC group that in the high ETC group $(P<0.01$ or $0.01<P<0.05)$. The gray value of SS immunoreactivity in the small intestine in the low RTC group was significantly higher than that in the low TC group after 7 days of administration $(P<0.01)$. After 28 days of administration, the gray value of SS immunoreactivity was significantly higher in the low RTC group than in the high TC group $(P<0.01)$. After 28 days of administration, compared with those in the low TC group, the gray values of SS immunoreactivity in each 
segment of the small intestine in the high and low ETC groups were significantly increased $(P<0.01)$. Compared with that in the low TC group, the gray value of SS immunoreactivity in the small intestine in the high TC group was significantly increased after 28 days of administration $(\mathrm{P}<0.01$ or $0.01<\mathrm{P}<0.05)$. Overall, after 7, 14, 21 and 28 days of administration, the effects of high doses of TC and its processed products on the gray value of SS immunoreactivity in the small intestine were significantly stronger than those of the low doses of these drugs.

\section{Discussion}

\section{Effects of TC and its processed products on SS immunoreactivity in the small intestine}

Somatostatin is a neuropeptide and a key regulator of the growth axis ${ }^{[9]}$. It is widely distributed in many tissues and organs of many animals, especially in the gastrointestinal tract and pancreas ${ }^{[10]}$. The effect of somatostatin on the gastrointestinal tract is complex; it inhibits the exocrine function of the stomach, pancreas and bile, decreases motility and influences absorption. Furthermore, SS inhibits the release of gastrointestinal hormones, resulting in alterations in the secretion of gastrointestinal hormones related to the digestive and absorption functions of the gastrointestinal tract ${ }^{[11]}$. In mice, somatostatin receptor subtype 1 (SSTR1) modulates the basal inhibition of growth hormone release ${ }^{[12]}$. SSTR2 plays an important role in the physiological function of the gastrointestinal tract ${ }^{[13]}$. In the present experiment, we found that the number of SS cells in the small intestines of mice increased with the prolongation of drug administration. This is consistent with the results of Zhang Sujuan ${ }^{[14]}$, who showed that the number of somatostatin-immunoreactive cells in the gastrointestinal tracts of mice during early postnatal development increased significantly with age. SS can inhibit many kinds of gastrointestinal hormones and enzymes and gastrointestinal motility. It is widely distributed in the small intestines of mice, but its density is low, which is beneficial for the release of other gastrointestinal hormones in the small intestine, especially $5-\mathrm{HT}$. In addition, it can balance the content of 5-HT.

After 7 days of administration, there was no significant difference in SS immunoreactivity. After 14 days of administration, with the prolongation of drug administration, the difference in SS immunoreactivity between each group and the control group was increased, which may have been related to changes in the drug concentration of TC and its processed products in the blood. Immunoreactivity in the high dosetreated group was significantly higher than that in the low dose-treated group after the same duration of administration, indicating that the effects of TC and its processed products on SS show a certain doseeffect relationship. If the dose is too small and the administration time is short, the regulatory effect is not obvious. The immunoreactivity of SS in the small intestines of mice in the RTC groups was lower than that in the ETC groups after the same period of administration, which indirectly indicated that RTC had a stronger inhibitory effect on the secretion of SS than ETC. After 28 days of administration, the immunoreactivity of SS in the small intestine in each treatment group was reduced to different degrees compared with that in the control group. We speculated that TC and its processed products could 
significantly inhibit the secretion of SS in the small intestines of mice, and the high dose of RTC $(4 \mathrm{~g} / \mathrm{kg})$ had the most significant effect. We speculated that after being processed by Rubia cordifolia $L$. and Euphorbia fischeriana Steud., the medicinal effect of TC was enhanced and that the secretion of SS cells was inhibited to different degrees. This may have been because Rubia cordifolia L. and Euphorbia fischeriana Steud changed the contents of some active components in TC, such as tannins and polyphenols, or because the processed products interacted with each other to form new components.

\section{Effects of TC and its processed products on the distribution and function of SS in the small intestine}

A large number of studies have shown that SS-IR cells not only regulate endocrine function but also regulate digestive function by external secretion ${ }^{[15-16]}$. Some scholars have found that there are substances expressed in the processes of SS-IR cells that contact adjacent cells, suggesting that SS-IR cells have local paracrine regulatory function ${ }^{[17]}$. In this experiment, we found that the number of SS-IR cells in each intestinal segment in the administration group was decreased compared with that in the control group. Therefore, it was speculated that RTC and ETC have a certain inhibitory effect on the SS endocrine pathway. A few spindle-shaped SS cells were distributed in the lamina propria, and their processes pointed to the surrounding capillaries. In addition, some SS cells were cone-shaped or ovalshaped and distributed among intestinal epithelial cells, and their processes pointed toward the lamina propria. This provided a morphological basis for SS secretion and entry of SS into the blood circulation through the lamina propria. We also found cone-shaped or spindle-shaped SS cells, which were located between intestinal mucosal epithelial cells in many places in the small intestine, with processes that extended into the digestive cavity or acinar cavity. This provided possible morphological evidence for the exocrine function of SS. However, there was no significant difference in SS cell density between the control group and the administration group, indicating that drug administration had little effect on the SS exocrine pathway.

\section{Conclusions}

In this experiment, we studied the effect of TC and its processed products on the secretion and distribution of somatostatin in the small intestines of mice, which was first reported in China. The results showed that two processed products of TC had different inhibitory effects on the secretion and release of somatostatin in the small intestine and that the efficacies both of the processed products were enhanced compared to that of TC to different degrees. Therefore, processed products of TC have great potential development and application prospects. Further analysis of the pharmacodynamic mechanism of processed products of TC is the main future research direction related to TC.

\section{Declarations}

Acknowledgment 
This research was supported by the Scientific Research Fund of Sichuan Provincial Education Department (17SZA0249, China).

\section{The conflict of interest statement}

The authors hereby declare that there are no conflicts of interest related to this article.

\section{Data availability statement}

The data used to support the findings of this study are included within the article.

\section{Abbreviations}

\begin{tabular}{ll} 
TC & Terminalia chebula Retz. \\
\hline RTC & Rubia cordifolia L.-processed Terminalia chebula Retz. \\
\hline ETC & Euphorbia fischeriana Steud per Terminalia chebula Retz. \\
\hline $\mathrm{SS}$ & somatostatin \\
\hline $\mathrm{g} / \mathrm{kg}$ & gram $/$ kilogram $^{-1}$ body weight \\
\hline $\mathrm{g} \cdot \mathrm{kg}^{-1} \mathrm{BW}$ & gram $\cdot k i l o g \mathrm{ram}^{-1}$ belsius \\
\hline${ }^{\circ} \mathrm{C}$ & Cour \\
\hline $\mathrm{h}$ & minute \\
\hline $\mathrm{min}$ &
\end{tabular}

Fig. $\quad$ Figure

\section{References}

[1] Kamal R A , Joshi R. Evaluation of antimicrobial properties of fruit extracts of Terminalia chebula against dental caries pathogens [J]. Jundishapur Journal of Microbiology, 2009, 2(3): 105-111.

[2] Gupta P C. Biological and pharmacological properties of Terminalia chebula retz. (haritaki)-an overview[J]. International of Journal of Pharmacy and Pharmaceutical Sciences, 2012, 4(3): 62-68.

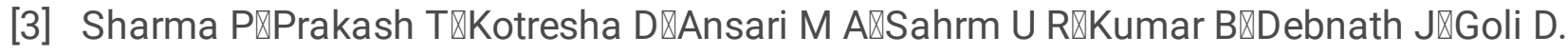
Antiulcerogenic activity of Terminalia chebula fruit in experimentally induced ulcer in rats[J]. Pharmaceutical Biology, 2011, 49(3): 262-268.

[4] Zhi-Qiang H, Eerdun. Study on Protective Effect of Processed Products of Traditional Mongolian Herbal Medicine Terminalia Chebula Retz. on Rats Liver Injury Induced by a- Naphthyl Isothiocyanate and

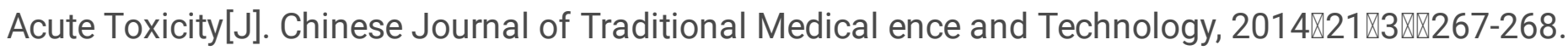


[5] Mao J Z ,Wang Z S. The Basic Study of Tibetan Medicine Processing [M]. BeiJing: China press of traditional Chinese Medicine. 2011:163-164.

[6] Schaefer A , Helga Mattheß, Pfitzer G , Köhle K. A centenary of gastrointestinal endocrinology[J]. Hormone and Metabolic Research, 2004, 36(11-12): 735-741.

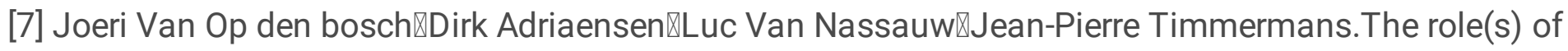
somatostatin, structurally related peptides and somatostatin receptors in the gastrointestinal tract: a review [J]. Regulatory Peptides, 2009,156(1-3): 1-8.

[8] Mao J Z ,Wang Z S. The Basic Study of Tibetan Medicine Processing [M]. BeiJing: China press of traditional Chinese Medicine. 2011:163-164.

[9] Jing Ma, Jie Chen, Bruno Louro, Rute S.T. Martins, Adelino V.M. Canario. Somatostatin 3 loss of function impairs the innate immune response to intestinal inflammation[J].Aquaculture and Fisheries $\mathbb{Z}$ 2020囚online 28 September》

https: //www.sciencedirect.com/science/article/pii/S2468550X20301234

[10] Patel Yogesh C. , Wheatley Thomas, Ning Chin.Multiple forms of immunoreactive somatostatin: comparison of distribution in neural and nonneural tissues and portal plasma of the rat [J]. Endocrinology ,1981,109:1943-1949.

[11] László Herszényi , Emese Mihály, Zsolt Tulassay. Somatostatin and the digestive system. Clinical experiences [J]. Orvosi Hetilap, 2013ه154(39):1535-1540.

[12] Kreienkamp H J, Akgün E, Baumeister $\mathrm{H}$, et al. Somatostatin receptor subtype 1 modulates basal inhibition of growth hormone release in somatotrophs[J]. FEBS Letters, 1999, 462(3): 464-466.

[13] Rong W, Winchester W J, Grundy D. Spontaneous hypersensitivity in mesenteric afferent nerves of mice deficient in the sst2 subtype of somatostatin receptor[J]. The Journal of Physiology, 2007, 581(2): 779-786.

[14] Zhang Sujuan, Wang Tong, Wang Dongxu, Cai Yujin, Li Wei, Jing Ya. Morphological study of 5-HT and somatostatin immunoreactive cells in the gastrointestinal tract during early postnatal development of mouse [J]. China Medical Herald , 2009, 6ख29®:7-10.

[15] Ahlman H, DeMagistris L, Zinner M, et al. Release of immunoreactive serotonin into the lumen of the feline gut in response to vagal nerve stimulation[J]. Science, 1981, 213(4513): 1254-1255.

[16] Huang X G, Wu X B. Immunohistochemical study on gastrointestinal endocrine cells of four reptiles[J]. World journal of gastroenterology, 2005, 11(35): 5498-5505. 
[17] Larsson L I, Goltermann N, de Magistris L, et al. Somatostatin cell processes as pathways for paracrine secretion[J]. Science, 1979, 205(4413): 1393-1395.

\section{Figures}
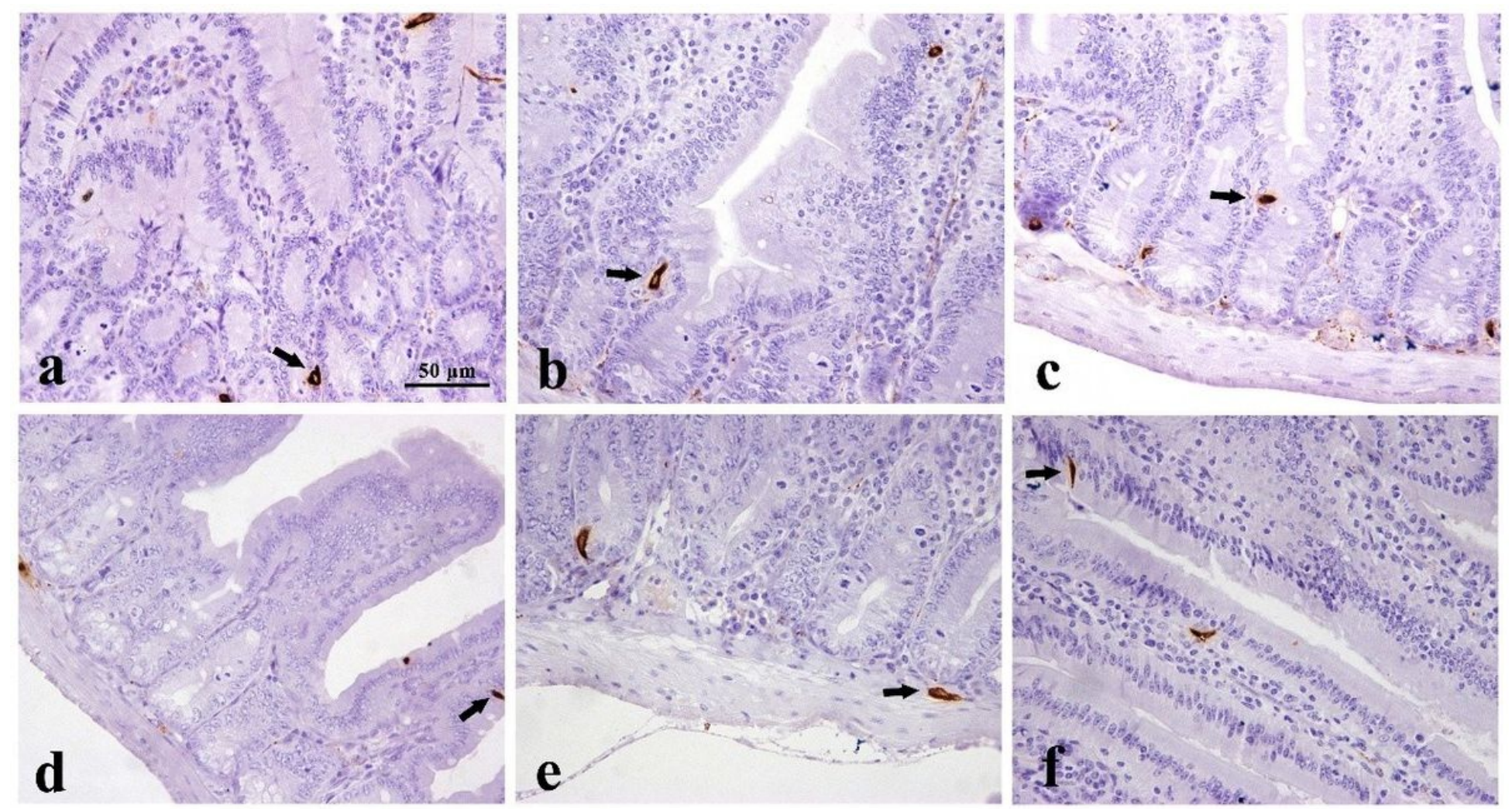

Figure 1

The SS cell local and morphology in the small intestines of each group (400x). a b: SS cells in the duodenum in the control group and the low RCT group at 28 days; c d: SS cells in the jejunum in the control group and the high RCT group at 14 days; e f: SS cells in the ileum in the control group and the high ECT group at 21 days. 

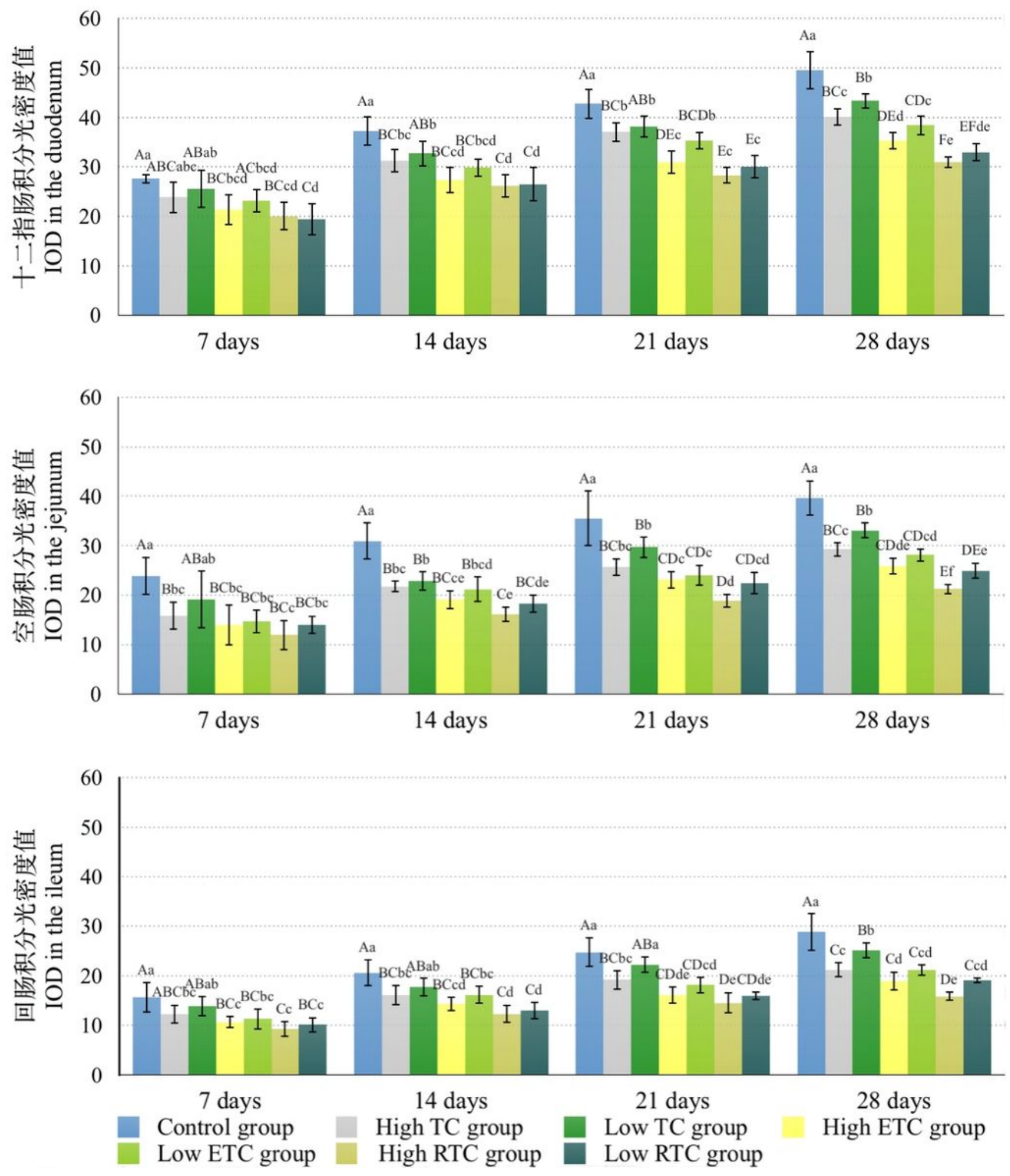

Figure 2

IOD of SS-IR cells in the small intestines. Note: In each histogram, small letters indicate a significant difference between the groups $(P<0.05)$, and capital letters indicate an extremely significant difference between the groups $(P<0.01)$ in the same segment of the intestine for the same drug. 


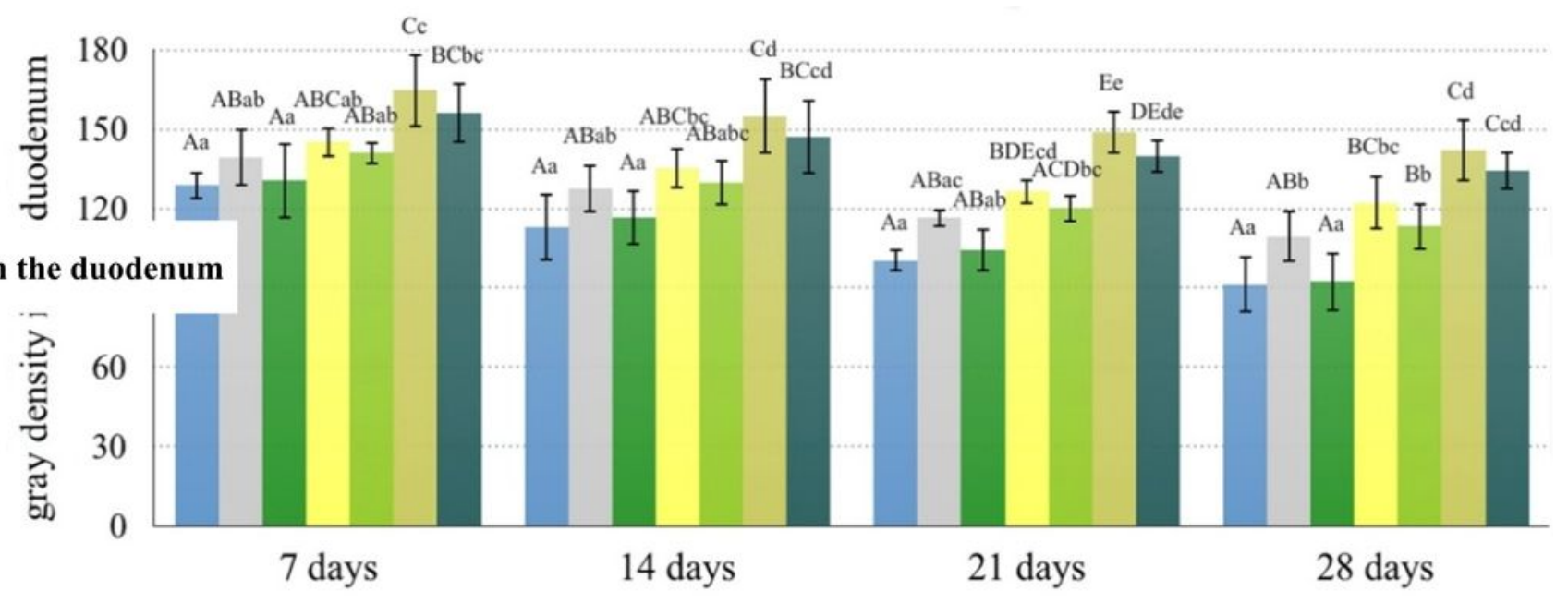

Gray value in the duodenum

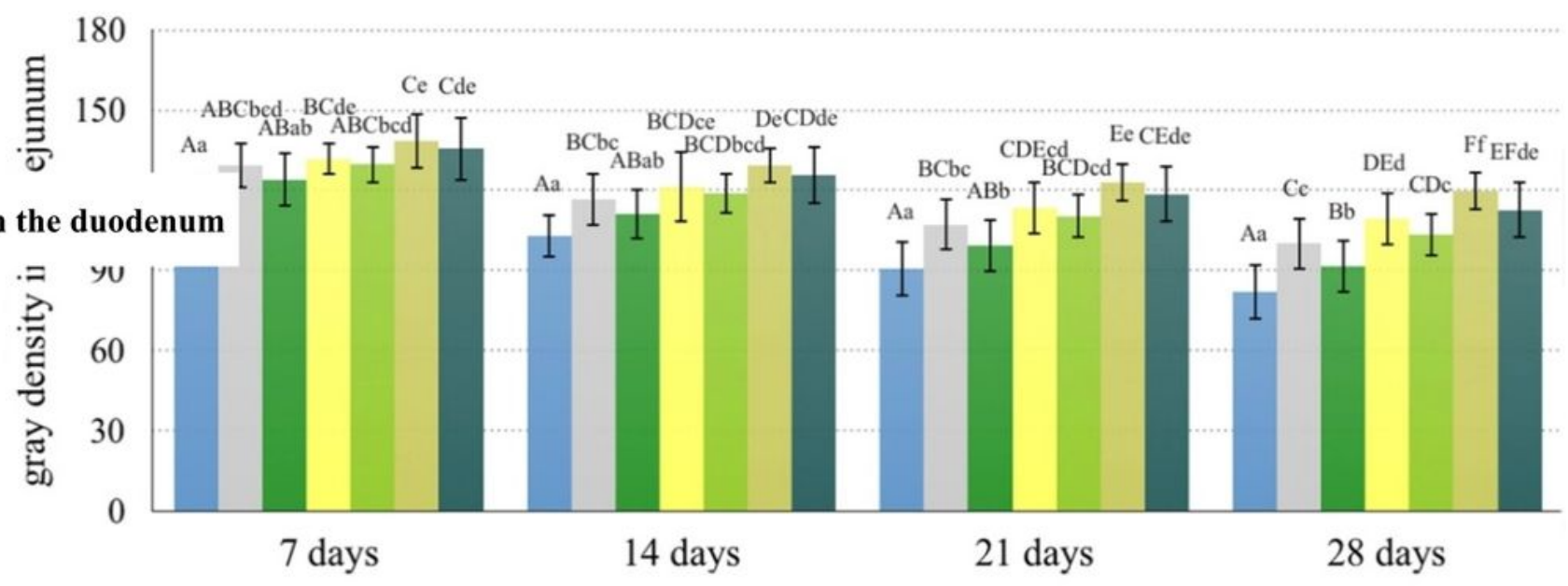

Gray value in the duodenum

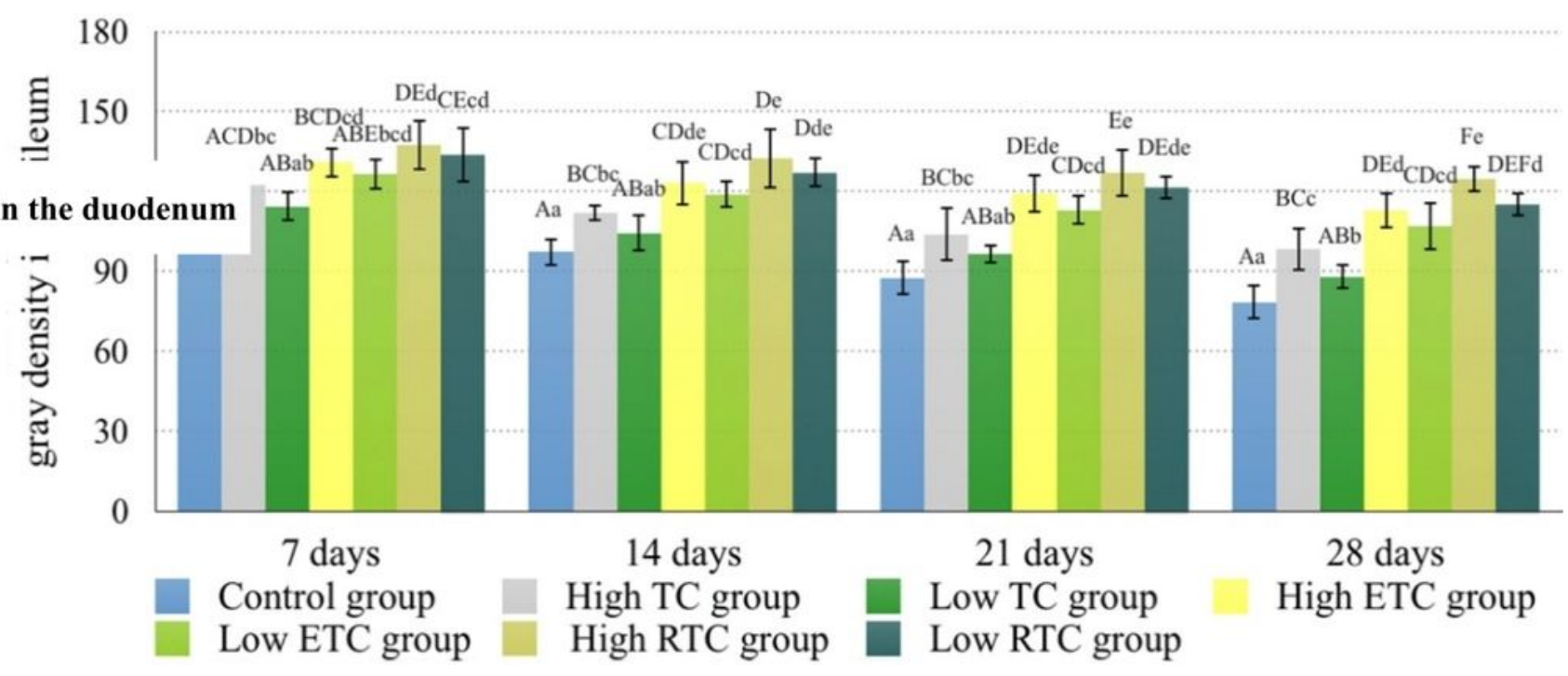

\section{Figure 3}

The gray value of SS-IR cells in the small intestines. Note: Same as in Fig. 2. 